\title{
Using Definitions to Provoke Deep Explorations into the Nature of Leadership
}

\author{
Deana M. Raffo \\ Associate Professor of Management \\ Jones College of Business \\ Middle Tennessee State University \\ Leigh A. Clark \\ Associate Professor of Management \\ Jones College of Business \\ Middle Tennessee State University
}

\begin{abstract}
Leadership is filled with concepts that often do not have an agreed upon definition. The purpose of this paper is to share a learning activity that provokes students' thinking about the nature of leadership using six leadership definitions. This activity is a dynamic starting place to explore what leadership is and is not, how it differs from management, a historical perspective of leadership, and students' diverse perspectives about leadership. This activity is a straightforward, critical thinking exercise that offers a conduit to a deeper understanding that how we define leadership says something about what we value in a leader. We suggest modifications to this definitional exercise and discuss how to use it in different teaching environments.
\end{abstract}

\section{Introduction}

Recent surveys of employers indicate a growing belief that new graduates lack some key job skills including the skill of critical thinking (e.g. Strauss, 2016; Selingo, 2015; Williams, 2017). A study of college students' higher-order thinking skills, found that $40 \%$ of college seniors did not have the level of complex reasoning skills needed for today's workforce. Furthermore, students in math or science scored much higher in critical thinking than students in business and other social sciences (Selingo, 2015). Another study by MindEdge found that young adults between ages 19 and 30 performed poorly on critical thinking measures (Williams, 2017)

The Association to Advance Collegiate Schools of Business (AACSB) specifies that accredited Bachelor's Degree business programs should include a focus on analytical skills and reflective thinking as general skills business students should develop. Often these skills are developed through project work involving "statistical techniques, data management, data analytics and information technology" (AACSB, 2017, 35). Watkins and Earnhardt (2015) observed that to develop students' critical thinking skills, instructors need to help students be aware of the thought processes and to approach reasoning in a disciplined or systematic way.

The Socratic method of teaching offers another way to sharpen critical thinking skills. This method uses "a prolonged series of questions and answers which refutes a moral assertion 
leading an opponent to draw a conclusion that contradicts his own viewpoint" (Tucker, 2007, p. 81). Through this directed questioning and dialogue, students are encouraged to critically think about their own views and question their assumptions and perspectives.

Following this approach, we created a critical thinking exercise that focuses on the term leadership. We employ a systematic process to prompt students to analyze the meanings of words, phrases, and definitions and to compare them to a student's experience to arrive at the definition that best reflects what the student believes or has experienced leadership to be. This exercise can be adapted for use in many different teaching environments. We first discuss the literature surrounding the definition or lack of a single definition for the term leadership followed by an overview of the defining leadership activity. We close with a discussion of additional uses for the exercise and provide some examples.

\section{Value of Defining Leadership as an Activity}

The way we define leadership - the words and phrases we use and their implied meanings - unveils how we view leadership and what we value in a leader. Kouzes and Posner (2017) say that leaders are attentive to the language and words they use because these words are metaphors for concepts that define attitudes and behaviors, among other things. When we are able to understand how we define leadership for ourselves, it empowers us to put it into action.

However, even prominent leadership scholars do not agree on how leadership is defined (Huber, 2002; Northouse, 2016; Rost, 1991). Definitions of leadership have evolved over time and leadership is complex, resulting in an array of perspectives, frameworks, and concepts. Since there is no single definition of leadership, how we define it becomes personal and reflects who we are, what we value, and the message we want to send to others as we express our views about leadership.

Leadership educators face a challenge when introducing leadership as a concept to students since there is no universal definition of leadership. However, this challenge can be an opportunity for us to acquaint students with the complexity of leadership by discussing its evolution, debunking myths, contrasting it with management, and examining leadership values that are latent in definitions.

Faculty are also challenged because many students do not believe they have much experience with leadership so they do not relate the discussion of leadership to an existing framework. We disagree. Leadership experience comes throughout life in a variety of ways (Nichols, 2016) and how we view leadership is a "personal phenomenon that cannot be meaningfully understood without taking into account the uniqueness of the leader" (Eriksen, 2007, p. 265). Through directed reflection, students can come to realize they have experiences with leadership such as being leaders on sports teams, as shift leaders at work, as officers in student organizations, or as informal leaders on team projects. They may not have been named or elected the leader but have emerged as a leader as needed. Students have also experienced effective or ineffective leadership in their roles as followers. This exercise breaks through surface level impressions of leadership and students' potential regurgitation of textbook or 
Internet definitions to facilitate their analyses of what leadership means to them based on what they have experienced.

\section{Review of Related Scholarship}

There are many ways to define leadership based on various perspectives related to the discipline, the evolution of leadership, and ways in which leadership has been conceptualized (Huber, 2002; Northouse, 2016; Rost, 1991). Defining leadership is complicated and complex. There are multiple dimensions to explore, values to contemplate, frameworks to study, principles to ponder, and scholarship to consider when defining leadership.

Rost (1991) found that scholars often do not define leadership. He undertook a study of 587 scholarly works that referred to leadership and found that more than $60 \%$ of them did not define the term leadership, even though it was the focus of the research.

Over time, the definition of leadership has changed, shifting focus from being leadercentric with a focus on control and power to one focused on process, influence, and relationships. In the book, Leadership for the Twenty-first Century, Rost (1991) described trends in this evolution in detail, citing seminal studies and writings on leadership over the span of nearly a century. Rost and Barker (2000) describe the $20^{\text {th }}$ century view of leadership as managementoriented, focused on superior/subordinate relationships, individualistic, goal/performanceoriented, and hierarchical. Conversely, they describe the post-industrial, social construct of leadership as inclusive, community-oriented, and complex. In Leadership: Theory and Practice, Northouse (2016) summarizes and outlines this evolution of leadership thought as summarized in the table, Evolution of Leadership Definitions (see Table 1).

Table 1. Evolution of Leadership Definitions (Rost, 1991; Northouse, 2016)

\begin{tabular}{ll}
\hline Decade & Leadership Definition Emphasis \\
\hline $1900-1920 \mathrm{~s}$ & control, power \\
$1930 \mathrm{~s}$ & traits, influence \\
$1940 \mathrm{~s}$ & groups \\
$1950 \mathrm{~s}$ & groups, relationships, goals, effectiveness \\
$1960 \mathrm{~s}$ & behavior \\
$1970 \mathrm{~s}$ & organizational behavior, reciprocal process \\
$1980 \mathrm{~s}$ & influence, traits, transformation \\
$21^{\text {st }}$ century & leadership vs. management, process, authenticity, values, follower focus
\end{tabular}

\section{Students' Perceptions and Experiences with Leadership}

Studies show that when surveyed about their knowledge of leadership, students often demonstrate the industrial perception of leadership, meaning the hierarchical view (e.g. Haber, 
2012; Ho \& Odom, 2015; Shertzer \& Schuh, 2004). However, the hierarchical view is not the contemporary view of leadership. Helping students navigate this complexity and understand leadership from a $21^{\text {st }}$ century perspective can be a challenge for leadership educators.

Ho and Odom (2015) examined "leadership mindsets" of undergraduate students studying leadership based on Komives et al.'s (2009) Leadership Identity Development Model. Like Komives et al., Ho and Odem found that juniors who had not studied leadership tend to have a more hierarchical, rather than a systematic, understanding of leadership than seniors do. They concluded that leadership coursework might facilitate an evolution in students' beliefs from a positional perspective to a more comprehensive view of leadership.

Similarly, Haber (2012) examined how college students define leadership. Ten definition themes in three broader categories emerged: leader/follower relationships, leader characteristics or behaviors, and leadership outcomes. This study's findings showed "that students have a fairly traditional understanding of leadership" (p. 45), meaning hierarchical views of leadership. Likewise, Shertzer and Schuh (2004) found that students generally viewed leadership as individualistic and positional, focused on power and influence.

It is not surprising that students would reflect the hierarchical view of leadership, as many of their experiences have been with hierarchical-type leaders. For example, many coaches, teachers, or shift leaders lead in this way. "I am the coach, and you do what I say when I say it." Many parents also lead the family in a hierarchical manner. Perhaps, students have hierarchical views on leadership because it is a prevalent perception of leadership. An effort by business school leaders to find a common definition of leadership among business faculty revealed that many faculty had views of leadership that reflected the older, hierarchical view of leadership (Artz, Grover, \& Shaffer, 2006).

It is also likely students have experienced leaders who lead by focusing on the relationships between leader and follower as with a coach who individualizes coaching to the needs of a player or a shift leader that worked with an employee individually to offer experiences he or she sought or needed. It is also probable that students have been part of student work groups that involved shared leadership or seen examples of a teacher or fellow student who embodied servant leadership qualities. Why then are students not reflecting these other contemporary leadership characteristics when surveyed about leadership? We believe they are not thinking deeply enough to realize they hold different views. They merely reflect or say what they think they are supposed to say or what reflects prevalent perceptions.

In summary, industrial perceptions of leadership dominate students' perceptions of leadership. This hierarchical view of leadership contradicts today's contemporary view of leadership that emphasizes relationships and process. "The industrial view of leadership is inadequate for educational purposes because it does not address the nature of the complex social relationships among people who practice leadership, nor does it accurately accommodate their purposes, motives and intentions" (Rost \& Barker, 2000, p. 3). One role of leadership educators is to debunk traditional leadership myths and facilitate a paradigm shift that promotes contemporary leadership values (Haber, 2012). The leadership definition exercise is a great tool to begin this paradigm shift. 


\section{Description of the Practice}

As an "Introduction to Leadership" exercise, students examine six definitions of leadership outlined below. Students are told that there is no "right" answer, since prominent leadership scholars constructed all of the definitions and dates are not provided on the student handout.

1. Leadership is an influence relationship among leaders and followers who intend real changes that reflect their mutual purposes (Rost, 1991).

2. Leadership is directing and coordinating the work of group members (Fiedler, 1967).

3. Leadership may be considered as the process (act) of influencing the activities of an organized group in its efforts toward goal setting and goal achievement (Stogdill, 1950).

4. Leadership is the art of mobilizing others to want to struggle for shared aspirations (Kouzes \& Posner, 1995, 2017).

5. Leadership can be defined as the process by which an agent induces a subordinate to behave in a desired manner (Bennis, 1959).

6. Leadership is the reciprocal process of mobilizing by persons with certain motives and values, various economic, political and other resources, in a context of competition and conflict, in order to realize goals independently or mutually helped by both leaders and followers (Burns, 1978).

Students are then instructed to individually rank these definitions from 1 "highest" to 6 "lowest" based on the definition they like the most to the least. They are also encouraged to circle, underline, and/or highlight words and phrases that they like or do not like, and make personal notes with each definition.

Next, students are asked to break apart in groups of about 3-4 students to come up with a group ranking. Within their groups, they are instructed to discuss why they ranked the definitions as they did and the words/phrases they liked or did not like. The discussion that students engage in within their groups is more important than the actual ranking.

Then, as a class, the groups share their top two definitions, then their bottom two definitions. We also discuss variations within the groups. Most importantly, we discuss the words/phrases that they liked and did not like in defining leadership. The instructor may use questions similar to these to facilitate the discussion:

- Which definition did your group rank the highest? Why did you do so?

- Which definition did your group rank the lowest? Why did you do so?

- Were there any words that you discussed in more detail? Share the main points of those discussions with us.

- What does the word "struggle" mean to you? What about "art"?

- If there was a definition not discussed so far, ask specifically about that definition and explore why it was not one that a group ranked high or low.

- What was your personal basis for selecting one definition over another?

- How did your personal leadership experience come into play when ranking the definitions? 


\section{Discussion of Outcomes and Results from the Exercise}

This activity is a positive and productive starting place to talk about what leadership is, how it differs from management, a historical perspective of leadership, and diverse viewpoints of leadership. It offers a conduit to a discussion that how we define leadership says something about what we value in a leader. It also allows students to first conceptualize leadership individually, based on their own experiences, before learning more (Artz et al., 2006).

Students tend to rank definitions 1 and 6 high, 2 and 5 low, with the others in between. Each definition was deliberately selected to provoke discussion and debate and takes 40-60 minutes to complete, depending on the time allotted for discussion and the type of related material (introduction to various theoretical perspectives, discussion about management verses leadership, etc.). The following provides a justification of why each definition was selected, the purpose it serves, and general observations.

High Ranking Definitions 1 and 6. Discussing the highly ranked definitions first allows for a constructive discussion about how we view leadership today. Students tend to single out concepts such as relationships, process, and mutual benefit/purpose to best describe how they think about leadership (or should think about it). This is an "aha moment" for many students as they had not previously thought about what leadership means to them and the words one might use to effectively describe leadership.

Low Ranking Definitions 2 and 5. The words "directing” and "coordinating" from definition 2 prompt students to discuss how they think about management differently from leadership, even if they have not considered this before (most have not). Definition 5 has a manipulation ring to it with the use of the word "induce," while "subordinate" implies a hierarchy and/or position. These notions point toward an industrial view of leadership and allow for a conversation that debunks myths that leadership is positional or hierarchical or involves manipulation.

Middle Ranking Definitions 3 and 4. These definitions tend to fall in the middle overall, while individual students may either like or dislike any of them. Definition 3 facilitates a discussion about influence and goals. Finally, definition 4 prompts students to think about leadership as an "art," meaning there is no one way to lead others. Students tend to either really like or not like the word "struggle," but it stimulates a discussion about leadership being difficult.

\section{Reflections of the Practitioners}

We have completed this activity with classes for nearly a decade and are always delighted with the results. It provokes a rich discussion about the nature of leadership and sets the stage for introducing the evolution of leadership theory and various perspectives in understanding leadership. The activity provides a nonthreatening way for students to consider leadership as being different from what they may have originally believed because they can see a stark contrast between industrial and post-industrial paradigm schools of thought. Students also begin 
to question pre-conceived notions of leadership - such as being the same as management, power, manipulation, control - and begin to experience a paradigm shift to a more contemporary view of leadership. On a side note, when completed at the beginning of the semester, this activity also allows us to set the tone for class where discussion, debate, and group work are encouraged and even expected.

\section{Recommendations and Modifications}

Faculty may consider choosing other leadership definitions to meet their student learning outcomes. For example, selecting more similarly worded definitions could prompt students to discuss finer details, even within the framework of one leadership theory or model. We chose definitions that provide an array of perspectives that give students a historical perspective and convey a variety of perspectives so that students can consider how particular words convey various messages or values in leadership. Faculty could also consider definitions from various theoretical perspectives. For example, students could compare various definitions of servant leadership or authentic leadership.

Another suggestion would be for students to consider non-academic ways to define leadership. Quotes from consultants, politicians, and business leaders could be used for this exercise as a supplementary exercise. Instructors may select quotes based on leadership concepts (e.g. innovation, vision, motivation), types of leaders, etc. The following questions may be posed to stimulate discussion and critical thinking:

- Why do you think that this person defined leadership this way?

- How does that definition fit the person's professional/career/political objectives?

- $\quad$ Are they defining leadership in such a way that they are suggesting particular 'needs' that they can meet?

- What are the hidden assumptions embedded in the definitions?

To help students dive deeper following the exercise, ask students to recall a time when they were a leader or took a leadership role and had a positive experience. Ask them to write down their thoughts about the experience, what went well, what were the challenges, and how they felt during and after the experience. Then ask them to compare their highest ranked definition with their personal leadership experience to see if their experience is reflected in the chosen definition. This will increase the student's self-knowledge that will help them continue to explore the concept of leadership throughout the course or training (Ericksen, 2007).

We recommend that as a concluding part of this activity, consider having students save their individual rankings and notes to revisit with an end-of-semester (final) paper. As a part of the final paper, we ask students to reflect on their top definition from the first day of class. Questions to ask them to consider include the following:

- Do they still like their top definition? Why? If not, what have they learned to change their mind?

- How would they change/tweak their top definition to more clearly describe their beliefs about leadership? 
- Is there a different definition from the literature that they prefer? Why?

- What words/phrases in the definition they have chosen communicate key values in the way they view leadership?

- Where do the ideas/concepts that are communicated in their definition intersect with various leadership theories?

\section{Using the Exercise with Other Terms and in Different Teaching Environments}

Online Courses. One approach to using this exercise in an online environment is first to have each student review the definitions and provide written responses to Step One of the exercise provided in the Appendix. Require students to submit their written responses by a designated due date before the online class proceeds to Step Two. For Step Two, assign class members to smaller discussion or online chat groups of 4-5 students. Provide them a longer period of time (5-7 days) to discuss online the definitions and complete Step Two to select the group's top two and bottom two definitions. Direct each group to post their choices and reasoning in a discussion board available to the entire class. If the online course allows for synchronous chat sessions, then require discussion in this format with a shortened timeframe for discussion. Otherwise, providing sufficient time for asynchronous discussion between group members is necessary.

The instructor then reviews the information and posts additional questions to dig deeper into why a group decided on the definitions they did for their top definitions and why they selected the definitions as being ranked lower. Require each group to answer the posted questions as well as reading and responding to posts on the class shared board. Strang (2011) found that the use of a Socratic questioning style in an online MBA discussion board yielded higher end of course essay grades than the traditional conversational discussion board suggesting that this exercise could also get to a deeper level of thinking in an online setting.

Ask that class members read the entire discussion and then revisit the definitions and select the definition that best represents leadership or to write a definition that best reflects leadership individually. Each class member is required to explain why they have selected that particular definition. Students then submit their final selection and the accompanying reflection to the instructor in a designated drop box.

Graduate or Executive Education. The definition exercise works without any modification with different types of students, although the discussion may be richer because of different leadership experiences upon which older students draw. We have used the exercise with great success in leadership trainings with working adults having various levels and types of leadership experiences. Sometimes these students can be more entrenched in their beliefs about the right definition but through group sharing in Step Two and questioning by the instructor, students carefully explore which definition best reflects what they believe and value in a leader. 


\section{Other Concepts to Define}

There are many concepts for which different definitions exist and where it may be beneficial for students to think critically about the various ways to define or understand a concept related to a particular leadership theory (e.g. trust, engagement, motivation). An instructor can quickly find different definitions of a concept by searching for research articles that mention defining the desired concept in the abstract. For example, Hosmer (1995) and Tan $\&$ Sutherland (2004) provide a variety of different definitions of "trust" in their articles. The definitions in such articles are a starting point for identifying a list of definitions for a concept to use in the exercise but we acknowledge this approach is only one method and there may be better definitions to use depending on your learning goals and course content. As an instructor, it will be important to develop some key questions to ask about the definitions or particular words. After using the exercise several times with students, an instructor will be able to identify common themes or outcomes that the exercise often yields.

\section{Conclusion}

Taking a deep dive into various leadership definitions by ranking them, analyzing them, and reflecting on them prompts an exploration of the complexities of leadership and allows students to think more deeply about what leadership means in contemporary society. Huber (2002) seems to agree explaining that she, in the role of leadership educator, does not struggle with a lack of a universally accepted definition.

The strength of this exercise is that it facilitates students reaching a deeper level of critical thinking in an efficient, nonthreatening way. It does not require a build-up of tools and techniques and can be used within the first weeks of a new class. The definition exercise is a powerful tool for any audience whether traditional, non-traditional, working adult or in an online environment. It has students quickly thinking on a deeper level without them realizing that is what they are doing.

\section{References}

AACSB (2017). Eligibility procedures and accreditation standards for business accreditation. Retrieved from www.aacsb.edu/accreditation/standards/2013-business

Artz, N., Grover, R. A., \& Shaffer, J. B. (2006, July). In pursuit of a common understanding of leadership: A case study of business school faculty and practitioner stakeholders. In Competition Forum, 4(2), 438-448. American Society for Competitiveness.

Bennis, W. G. (1959). Leadership theory and administrative behavior: The problem with authority. Administrative Science Quarterly, 4, 259-301. doi:10.2307/2390911

Burns, J. M. (1978). Leadership. New York: Harper \& Row. 
Eriksen, M. (2007). Personal leadership conundrum. Journal of Management Education, 31(2), 263-277.

Fiedler, F. E. (1967). A theory of leadership effectiveness. New York: McGraw Hill.

Haber, P. (2012). Perceptions of leadership: An examination of college students' understandings of the concept of leadership. Journal of Leadership Education, 11(2), 26-51.

Ho, S. P., \& Odom, S. F. (2015). Mindsets of leadership education undergraduates: An approach to program assessment. Journal of Leadership Education, 14(1).

Hosmer, L. T. (1995). Trust: The connecting link between organizational theory and philosophical ethics. Academy of Management Review, 20(2), 379-403.

Huber, N. S. (2002). Approaching leadership education in the new millennium. Journal of Leadership Education, 1(1), 25-34.

Komives, S. R., Longerbeam, S. D., Mainella, F., Osteen, L., Owen, J. E., \& Wagner, W. (2009). Leadership identity development: Challenges in applying a developmental model. Journal of Leadership Education, 8(1), 11-47.

Kouzes, J.M. \& Posner, B.Z. (1995) The leadership challenge: How to keep getting extraordinary things done in organizations ( $2^{\text {nd }}$ ed.). San Francisco, CA: Jossey-Bass

Kouzes, J. M., \& Posner, B. Z. (2017). The leadership challenge: How to make extraordinary things happen in organizations (6th ed.). Hoboken, NJ: Wiley.

Nichols, A. L. (2016). What do people desire in their leaders? The effect of leadership experience on desired leadership traits. Leadership \& Organization Development Journal, 37(5), 658-671. doi: 10.1108/LODJ-09-2014-0182

Northouse, P. G. (2016). Leadership: Theory and practice (7th ed). Thousand Oaks, CA: Sage.

Rost, J. C. (1991). Leadership for the twenty-first century. Westport, CT: Praeger.

Rost, J. C., \& Barker, R. A. (2000). Leadership education in colleges: Toward a 21st century paradigm. Journal of Leadership Studies, 7(1), 3-12.

Selingo, J. J. (2015, January 26). Why are so many college students failing to gain job skills before graduation? The Washington Post. Retrieved from https://www.washingtonpost.com/news/grade-point/wp/2015/01/26/why-are-so-manycollege-students-failing-to-gain-job-skills-before-graduation/

Shertzer, J. E., \& Schuh, J. H. (2004). College student perceptions of leadership: Empowering and constraining beliefs. NASPA Journal, 42(1), 111-131. doi: 10.2202/1949-6605.1417 
Stogdill, R. M. (1950). Leadership, membership and organization. Psychological Bulletin, 47, 114. doi: $10.1037 / \mathrm{h} 0053857$

Strang, K. D. (2011). How can discussion forum questions be effective in online MBA courses? Campus-Wide Information Systems, 28(2), 80-92.

Strauss, K. (2016, May 17). These are the skills bosses say new college grads do not have. Forbes. Retrieved from https://www.forbes.com/sites/karstenstrauss/2016/05/17/theseare-the-skills-bosses-say-new-college-grads-do-not-have/\#21e5f4ed5491

Tan, F. B., \& Sutherland, P. (2004). Online consumer trust: A multi-dimensional model. Journal of Electronic Commerce in Organizations, 2(3), 40-58.

Tucker, A. A. (2007). Leadership by the Socratic method. Air \& Space Power Journal, 21(2), 80-87.

Watkins, D. V. \& Earnhardt, M. P. (2015). Developing critical thinking within a Master of Science in Leadership Program. Academy of Educational Leadership Journal, 19(1), 184194.

Williams, T. (2017, May 30). GoodCall Study: Nearly half of millennials get an ' $F$ ' in critical thinking. Retrieved from https://www.goodcall.com/news/critical-thinking-011043

\section{Author Biographies}

Deana Raffo, Ed.D. is Associate Professor of Management at Middle Tennessee State University where she coordinates the Leadership Studies minor and directs the Institute of Leadership Excellence. Her research interests include leadership education and the introspective qualities in leadership. She received a Doctor of Education in Administration and Supervision from Tennessee State University. deana.raffo@mtsu.edu

Leigh Anne Clark is Associate Professor of Management at Middle Tennessee State University. She teaches and researches in the areas of business ethics, privacy, nonprofit management, leadership, and organizational behavior. She received a Doctor of Business Administration in Organization Studies from Southern Illinois University and Doctor of Jurisprudence from Emory University. 1a.clark@mtsu.edu 